\title{
EFFECT OF PLANTING AGE AND SPACING ON ENERGY PROPERTIES OF Eucalyptus grandis W. Hill EX Maiden ${ }^{1}$
}

Elder Eloy ${ }^{2 *}$, Dimas Agostinho da Silva ${ }^{3}$, Denise Schmidt ${ }^{4}$, Rômulo Trevisan ${ }^{2}$, Braulio Otomar Caron ${ }^{4}$ and Elvis Felipe Elli ${ }^{5}$

\footnotetext{
${ }^{1}$ Received on 30.06.2015 accepted for publication on 02.06.2016.

${ }^{2}$ Universidade Federal de Santa Maria, Departamento de Engenharia Florestal, Frederico Westphalen, RS - Brasil. E-mail: <eloyelder@yahoo.com.br>and <romulo_trevisan@yahoo.com.br>.

${ }^{3}$ Universidade Federal do Paraná, Departamento de Engenharia e Tecnologia Florestal, Curitiba, PR - Brasil. E-mail: $<$ dimas.agostinho.silva@gmail.com>.

${ }^{4}$ Universidade Federal de Santa Maria, Departamento de Ciências Agronômicas e Ambientais, Frederico Westphalen, RS - Brasil. E-mail: <schmidtbr2000@yahoo.com.br>and <otomarcaron@yahoo.com.br>.

${ }^{5}$ Universidade Federal de Santa Maria, Programa de Pós-Graduação em Agronomia, Agricultura e Ambiente, Frederico Westphalen, RS - Brasil. E-mail: <elvisfelipeelli@yahoo.com>.

*Corresponding author.
}

\begin{abstract}
This study aimed to determine the effect of planting age and spacing on energy properties of different compartments of the biomass of Eucalyptus grandis W. Hill ex Maiden, disseminated in different spacings: $2.0 \times 1.0 \mathrm{~m}, 2.0 \times 1.5 \mathrm{~m}, 3.0 \times 1.0 \mathrm{~m} \mathrm{e} 3.0 \times 1.5 \mathrm{~m}$, in the $1^{\text {st }}, 3^{\text {rd }}$ and $5^{\text {th }}$ year after the planting. The present study was carried out as an experiment installed in an experimental design of randomized complete blocks in three replications. Variables determined were Biomass (BIO), Gross Calorific Value (GCV), Basic Density (BD), Energy Productivity (EP), Energy Density (ED), Fixed Carbon Content (FCC), Volatile Material Content (VMC), and Ash Content (AC). Ages have an effect on all studied variables, and in the 5th year after planting, the largest BIO, EP, BD, ED and FCC values are checked. The planting spacings induce different productions of $\mathrm{BIO}$ and $\mathrm{EP}$, with a trend towards lower values with increasing planting spacing in all assessed periods. The compartments of trees influence BIO, GCV, FCC, VMC and AC variables. Regarding to energy, the higher the age and lower the planting spacing, the better the energy properties of biomass.
\end{abstract}

Keywords: Biomass; Gross Calorific Value; Energy Productivity.

\section{EFEITO DA IDADE E DO ESPAÇAMENTO DE PLANTIO NAS PROPRIEDADES ENERGÉTICAS DO Eucalyptus grandis W. Hill ex Maiden}

RESUMO-Esse trabalho teve como objetivo determinar o efeito da idade e do espaçamento de plantio nas propriedades energéticas de diferentes compartimentos da biomassa de Eucalyptus grandis W. Hill ex Maiden, distribuida em diferentes espaçamentos: 2,0x1,0 m, 2,0x1,5 m, 3, 0x1,0 m e 3,0x1,5 m, no $1^{\circ}, 3^{\circ}$ e $5^{\circ}$ ano após o plantio. O presente trabalho foi realizado em um experimento instalado em delineamento experimental de blocos completos casualizados em três repetições. Foram determinadas as variáveis biomassa (BIO), poder calorífico superior (PCS), massa específica básica (ME), produtividade energética (PE), densidade energética $(D E)$, teor de carbono fixo (CF), teor de material volátil (MV) e teor de cinzas (CZ). As idades proporcionam um efeito em todas as variáveis analisadas, sendo que no $5^{\circ}$ ano após o plantio, são verificados os maiores valores de BIO, PE, ME, DE e CF. Os espaçamentos de plantio induzem a diferentes produções de BIO e $P E$, com uma tendência de redução dos valores com o aumento do espaçamento de plantio, em todos os periodos avaliados. Os compartimentos das árvores influenciam nas variáveis $B I O, P C S, P E, C F, M V$ e CZ. Do ponto de vista energético, quanto maior a idade e menor o espaçamento de plantio, melhores são as propriedades energéticas da biomassa.

Palavras-chave: Biomassa; Poder calorifico superior, Produtividade energética. 


\section{INTRODUCTION}

The development of mankind is closely associated with an increase in energy consumption and the rational use of various sources of energy. Over the past decades, that energy demand has been mainly based on nonrenewable sources, setting off a series of questions regarding energy supply and environmental and economic balance. So, many countries have been looking for alternatives to minimize these problems, particularly by intensifying the use of renewable sources, including forest biomass.

With the growing demand for renewable energy sources, studies regarding the potential of generation originating from forest biomass have been conducted in Brazil and in the world, reporting the potential of biomass for a clean energy production, such as those developed by Lemenih and Bekele (2004); Lima et al. (2011); Vidaurre et al. (2012); Protásio et al. (2013); Caron et al. (2015); Eloy et al. (2015). However, to increase the efficiency of the conversion of wood into energy, the adoption of the most appropriate technologies is needed to assess its true potential in the carbonization, heat making, and power cogeneration (SILVA et al., 2012); thus, turning expectations regarding the use of forest biomass as a feedstock for power generation auspicious.

In Brazil, in 1940, approximately $80 \%$ of energy consumption came from wood. In 1970 this percentage was reduced to $45 \%$, in 2013 to $8.3 \%$ (EPE, 2014). Despite this decrease in participation of wood as an energy source, in quantitative terms, the consumption has not changed significantly, evidencing that there is a captive market for the use of forest biomass as an energy source.

The selection of species, both native and exotic, is extremely important for its use as an alternative energy source. Nonetheless, for this to be viable, knowledge regarding the essential characteristics is necessary for that use, in relation to ecological and silvicultural factors and those ones related to energy potential, supporting, thus, the decision-making for implementation of forest plantations (MOREIRA, 2011).

The use of wood for energy purposes is elevated in Brazil, mainly motivated by the diversity of species with energetic properties. Thus, the presence of established forest experiments with known original conditions of location, planting and ages of trees is essential, for new information regarding the qualification of species for energy generation to be allowed and, by extension, with propensity to formation of forest regions for fuelwood material production.

One of the main factors that affects the formation of forests is the spacing practiced in plantings, because it has silvicultural, technological and economic implications, interfering with growth rates of plants, cutoff age, quality of wood, forestry practices employed and, therefore, production costs (ELOY, 2013). Thus, when it aims to timber production for energy purposes, normally recommended to be narrower spacing plant in order to produce a greater volume of biomass per unit area in less time possible.

In this context, this study aimed to determine the effect of planting age and spacing on energy properties of different compartments of the biomass of Eucalyptus grandis W. Hill ex Maiden.

\section{MATERIALS AND METHODS}

\subsection{Characterization of the study area}

The work was carried out in the experiment located in an area pertaining to the Federal University of Santa Maria (UFSM) under geographic coordinates $27^{\circ} 22^{\prime} \mathrm{S}$; $53^{\circ} 25^{\prime} \mathrm{W}, 480 \mathrm{~m}$ altitude, in the city of Frederico Westphalen, Rio Grande do Sul.

According to the Köppen climate classification, the climate in this region is Cfa, i.e. Humid subtropical climate, with an average annual temperature of $19.1^{\circ}$ $\mathrm{C}$, varying with maximum of $38^{\circ} \mathrm{C}$ and minimum of $0^{\circ} \mathrm{C}$, with an average annual rainfall of $1606 \mathrm{~mm}$. The experimental area is far from Iraí, the city taken as a reference for the data of climate classification, from approximately $30 \mathrm{~km}$. As proposed by Maluf(2000), Iraí has an average annual temperature of $18.8^{\circ} \mathrm{C}$ and an average temperature, in the coldest month, of $13.3^{\circ} \mathrm{C}$.

The experiment was conducted using a design of experimental randomized complete blocks. They were characterized by a $3 \times 4 \times 4$ factorial, i.e. three periods ( $1^{\text {st }}, 3^{\text {rd }}$ and $5^{\text {th }}$ years after planting), four planting spacings $(2.0 \times 1.0 \mathrm{~m} ; 2.0 \times 1.5 \mathrm{~m} ; 3.0 \times 1.0$ and $3.0 \times 1.5 \mathrm{~m})$ and four compartments of trees (wood, bark, branch and leaf) in three replications. The block includes 16 experimental units, each of which has 45 plants located in five planting rows. 
The soil of the area is classified as typical dystrophic Red Latosol, clayey texture, deep and well-drained corresponding to Passo Fundo mapping unit (EMBRAPA, 2006).

\subsection{Sampling}

The destructive assessments of the trees were carried out in three different periods: in $1^{\text {st }}$ year (2009), $3^{\text {rd }}$ year (2011) and $5^{\text {th }}$ year (2013), after planting the experiment, when 36 trees were assessed per period. From those, six discs were removed with approximately two centimeters thick, in the following positions along the stem: $0 \%$ (basis), $1.30 \mathrm{~m}$ (diameter at breast height - DBH), $25 \%, 50 \%, 75 \%$ and $100 \%$ of the total height of the tree, and also two symmetrically opposed wedges of each disk were selected.

Samples of branches and leaves were collected from the plant in a stratified manner, i.e. the lower, middle and upper layer of the canopy of the trees, in order to obtain a homogeneous material that represents the entire length of the canopy. These were identified and taken to a drying and air circulation and renewal oven, in order to obtain the dry product. The samples of wood, bark, leaf and brunch were dried at $103{ }^{\circ} \mathrm{C}$ at $0 \%$ moisture, to determine the respective humidity content.

\subsection{Characterization of the assessments performed}

To determine the biomass (BIO), the direct method was used, which consisted on cutting and weighing the different compartments of the trees (SANQUETTA, 2002). The total fresh masses of sampled trees were determined under field conditions, and samples were taken from each compartment to obtain the moisture content in the laboratory.

For determining the gross calorific value (GCV) and the Immediate Chemical Analysis (ICA), materials obtained in sampling were used, that were grounded into a slicer with a 40-mesh sieve, in order to obtain a thinner and more uniform material. Evaluations of the GCV were performed using a digital bomb calorimeter, C5000 Cooling System model, IKA Werke, with adiabatic operating principle, according to the technical standard NBR 8633 (ABNT, 1984), and, in the case of the ICA, was used the technical standard 8112 NBR (ABNT, 1986), from which were obtained the concentrations of volatile, ashes and fixed carbon materials.
To determine the Basic Density (BD), the materials obtained in the sampling were used. The procedures were performed according to the technical standard NBR 11941 (ABNT, 2003).

For determining the Energy Productivity (EP), the $\mathrm{BIO}$ values with their respective GCV were multiplied according to the following expression:

\section{$\mathrm{EP}=\mathrm{BIOxGCV}$}

Where: $\mathrm{EP}=$ Energy Productivity $\left(\mathrm{Gcal} \mathrm{ha}^{-1}\right)$; BIO $=$ Dry Biomass of each compartment (ton ha-1) and $\mathrm{GCV}=$ Gross Calorific Value $\left(\mathrm{kcal} \mathrm{kg}^{-1}\right)$.

To determine the Energy Density (ED), BD and GCV values were multiplied according to the following expression:

\section{$\mathrm{ED}=\mathrm{BDxGCV}$}

Where: $\mathrm{ED}=$ Energy Density $\left(\mathrm{kcal} \mathrm{m}^{-3}\right) ; \mathrm{BD}=$ wood Basic Density according to the volume of the tree $\left(\mathrm{kg} \mathrm{m}^{-3}\right)$ and $\mathrm{GCV}=$ Gross Calorific Value $\left(\mathrm{kcal} \mathrm{kg}^{-1}\right)$.

\subsection{Data Analysis}

The obtained data was subjected to statistical analysis, which proceeded with the test assumption of homogeneity of variances, analysis of variance, regression analysis, F-test and Tukey's range test at $5 \%$ probability of error.

\section{RESULTS}

Analysis of variance revealed differences among the three studied periods and among the four compartments of the trees, for all analyzed variables. Likewise, this characteristic was observed among the four planting spacings for variables BIO and EP.

In the $1^{\text {st }}$ year of assessment, BIO and EP did not differ among the different compartments of the trees. In GCV and FCC cases, a difference was observed: the leaf showed the highest average values. Similarly, the same variation was observed in AC and VMC for bark and wood compartments, respectively. In BD and wood ED cases, the highest values were $0.391 \mathrm{~g} \mathrm{~cm}^{-3}$ and $1.770 \mathrm{Gcal} \mathrm{m}^{-3}$, respectively (Table 1 ).

In the $3^{\text {rd }}$ year of assessment, the highest BIO values were observed in the wood compartment in smaller planting spacings. Also, this characteristic was observed for EP in the same compartment. The

Revista Árvore, Viçosa-MG, v.40, n.4, p.749-758, 2016

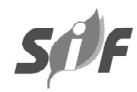


highest average values of GCV were reported for the leaf. Nevertheless, peel presented the lowest GCV values for all the spacings (Table 2).

As observed in the $3^{\text {rd }}$ year of assessment, at $5^{\text {th }}$ year the production of BIO and EP of the wood was different and statistically superior to other compartments of the trees. Just as in the two previous periods, in the $5^{\text {th }}$ year of assessment the highest average values were observed in the leaf, detecting maximum values of 5,055 kcal kg-1 (Table 3).

For FCC, in general, it was reported the highest average values for the bark, and the lowest ones for the branch compartment, which was different and inferior inside spacings for most of the other compartments.
Nevertheless, the highest average values for VMC were reported for wood, being statistically higher than bark and leaf in all spacings (Table 3 ).

From the BIO analysis of the different compartments of trees in relation to the four planting spacings, a direct relationship with the planting density in the three ages was observed. That is, in treatments with higher densities were observed higher BIO values, when compared with lower density spacings, and decreasing trends of this variable in the different compartments of the plant can be observed, due to the increase of usable area.

In Figure 1, regression equations of the different compartments over the three periods are presented,

Table 1 - Average test for energy variables of the compartments of Eucalyptus grandis, distributed in different spacings, one year after planting in the city of Frederico Westphalen-RS.

Tabela 1 - Teste de médias para as variáveis energéticas dos compartimentos das árvores de Eucalyptus grandis, distribuídas em diferentes espaçamentos, um ano após o plantio, no município de Frederico Westphalen-RS.

\begin{tabular}{|c|c|c|c|c|c|}
\hline \multirow[t]{2}{*}{ Varible } & \multirow[t]{2}{*}{ Comp. } & \multicolumn{4}{|c|}{ Spacing $(\mathrm{m})$} \\
\hline & & $2.0 \times 1.0$ & $2.0 \times 1.5$ & $3.0 \times 1.0$ & $3.0 \times 1.5$ \\
\hline \multirow{5}{*}{$\begin{array}{l}\text { Biomass } \\
\left(\text { ton } \mathrm{ha}^{-1} \text { ) }\right.\end{array}$} & Wood & $2.759 \mathrm{aA}$ & $1.801 \mathrm{aAB}$ & $1.059 \mathrm{aB}$ & $0.739 \mathrm{aB}$ \\
\hline & Bark & $0.387 \mathrm{bA}$ & $0.261 \mathrm{aB}$ & $0.175 \mathrm{aC}$ & $0.160 \mathrm{aC}$ \\
\hline & Branch & $2.376 \mathrm{aA}$ & $1.425 \mathrm{aAB}$ & $1.090 \mathrm{aB}$ & $0.996 \mathrm{aB}$ \\
\hline & Leaf & $4.663 \mathrm{aA}$ & $2.533 \mathrm{aB}$ & $2.297 \mathrm{aB}$ & $1.929 \mathrm{aB}$ \\
\hline & Total & $10.185 \mathrm{~A}$ & $6.020 \mathrm{~B}$ & $4.621 \mathrm{C}$ & $3.824 \mathrm{D}$ \\
\hline \multirow{4}{*}{$\begin{array}{l}\text { Energy } \\
\text { Productivit } \\
\left(\text { Gcal ha }^{-1}\right)\end{array}$} & Wood & $12.496 \mathrm{aA}$ & $8.240 \mathrm{aA}$ & $4.681 \mathrm{aB}$ & $3.212 \mathrm{aB}$ \\
\hline & Bark & $1.473 \mathrm{aA}$ & $0.996 \mathrm{aA}$ & $0.689 \mathrm{aA}$ & 0.618 aA \\
\hline & Branch & $10.376 \mathrm{aA}$ & $6.326 \mathrm{aAB}$ & $4.820 \mathrm{aB}$ & $4.322 \mathrm{aB}$ \\
\hline & Leaf & $21.818 \mathrm{aA}$ & $12.120 \mathrm{aB}$ & $10.798 \mathrm{aB}$ & $9.670 \mathrm{aB}$ \\
\hline \multirow{4}{*}{$\begin{array}{l}\text { Gross Calorific } \\
\text { Value }\left(\mathrm{kcal}^{\mathrm{kg}} \mathrm{kg}^{-1}\right)\end{array}$} & Wood & $4529 \mathrm{ab}$ & $4575 \mathrm{ab}$ & $4420 \mathrm{~b}$ & $4346 \mathrm{~b}$ \\
\hline & Bark & $3805 \mathrm{c}$ & $3817 \mathrm{c}$ & $3937 \mathrm{c}$ & $3864 \mathrm{c}$ \\
\hline & Branch & $4367 \mathrm{~b}$ & $4439 \mathrm{~b}$ & $4422 \mathrm{~b}$ & $4339 \mathrm{~b}$ \\
\hline & Leaf & 4679 a & $4785 \mathrm{a}$ & $4701 \mathrm{a}$ & $5013 \mathrm{a}$ \\
\hline \multirow{4}{*}{$\begin{array}{l}\text { Fixed } \\
\text { Carbon (\%) }\end{array}$} & Wood & $17.99 \mathrm{ab}$ & $12.69 \mathrm{c}$ & $15.32 \mathrm{~b}$ & $15.16 \mathrm{~b}$ \\
\hline & Bark & $15.38 \mathrm{~b}$ & $16.40 \mathrm{~b}$ & $19.65 \mathrm{a}$ & $16.68 \mathrm{ab}$ \\
\hline & Branch & $16.86 \mathrm{ab}$ & $14.73 \mathrm{bc}$ & $14.83 \mathrm{~b}$ & $15.41 \mathrm{~b}$ \\
\hline & Leaf & $18.20 \mathrm{a}$ & $18.70 \mathrm{a}$ & $19.83 \mathrm{a}$ & $18.77 \mathrm{a}$ \\
\hline Volatile & Wood & $80.96 \mathrm{ab}$ & $83.28 \mathrm{a}$ & $83.74 \mathrm{a}$ & $83.42 \mathrm{a}$ \\
\hline \multirow[t]{3}{*}{ Material (\%) } & Bark & $76.47 \mathrm{c}$ & $76.43 \mathrm{~b}$ & $74.48 \mathrm{~b}$ & $75.62 \mathrm{~b}$ \\
\hline & Branch & $78.85 \mathrm{bc}$ & $83.56 \mathrm{a}$ & $81.98 \mathrm{a}$ & $82.80 \mathrm{a}$ \\
\hline & Leaf & $82.26 \mathrm{a}$ & $78.41 \mathrm{~b}$ & $75.80 \mathrm{~b}$ & $77.55 \mathrm{~b}$ \\
\hline \multirow{4}{*}{ Ash Content (\%) } & Wood & $1.23 \mathrm{~d}$ & $0.99 \mathrm{~d}$ & $1.21 \mathrm{~d}$ & $1.12 \mathrm{~d}$ \\
\hline & Bark & $6.83 \mathrm{a}$ & $6.87 \mathrm{a}$ & $6.17 \mathrm{a}$ & $6.50 \mathrm{a}$ \\
\hline & Branch & $3.00 \mathrm{c}$ & $2.05 \mathrm{c}$ & $2.70 \mathrm{c}$ & $2.26 \mathrm{c}$ \\
\hline & Leaf & $4.34 \mathrm{~b}$ & $3.79 \mathrm{~b}$ & $4.42 \mathrm{~b}$ & $4.17 \mathrm{~b}$ \\
\hline$\overline{\mathrm{BD}\left(\mathrm{g} \mathrm{cm}^{-3}\right)}$ & Wood & 0.382 & 0.387 & 0.390 & 0.391 \\
\hline $\mathrm{ED}\left(\mathrm{Gcal} \mathrm{m} \mathrm{m}^{-3}\right)$ & Wood & 1.730 & 1.770 & 1.724 & 1.699 \\
\hline
\end{tabular}

Where: $\mathrm{BD}=$ Basic Density; $\mathrm{ED}=$ Energy Density; Comp. = compartments; Averages followed by lowercase letters in the same column and equal capital letters in the line do not differ among species and spacings, respectively, $5 \%$ of error probability according to Tukey's range test.

Revista Árvore, Viçosa-MG, v.40, n.4, p.749-758, 2016 
Table 2 - Average test for energy variables of the compartments of Eucalyptus grandis, distributed in different spacings, three years after planting in the city of Frederico Westphalen-RS.

Tabela 2 - Teste de médias para as variáveis energéticas dos compartimentos das árvores de Eucalyptus grandis, distribuidas em diferentes espaçamentos, três anos após o plantio, no municipio de Frederico Westphalen-RS. .

\begin{tabular}{|c|c|c|c|c|c|}
\hline \multirow[t]{2}{*}{ Varible } & \multirow[t]{2}{*}{ Comp. } & \multicolumn{4}{|c|}{ Spacing (m) } \\
\hline & & $2.0 \times 1.0$ & $2.0 \times 1.5$ & $3.0 \times 1.0$ & $3.0 \times 1.5$ \\
\hline \multirow{5}{*}{$\begin{array}{l}\text { Biomass } \\
\left(\text { ton } \mathrm{ha}^{-1}\right)\end{array}$} & Wood & $90.988 \mathrm{aA}$ & $47.636 \mathrm{aB}$ & $46.888 \mathrm{aB}$ & $27.461 \mathrm{aC}$ \\
\hline & Bark & $16.284 \mathrm{bA}$ & $15.553 \mathrm{bB}$ & $13.536 \mathrm{bB}$ & 6.998 bC \\
\hline & Branch & $18.140 \mathrm{bA}$ & $11.772 \mathrm{bB}$ & $13.319 \mathrm{bC}$ & $8.130 \mathrm{bD}$ \\
\hline & Leaf & $17.454 \mathrm{bA}$ & $15.932 \mathrm{bC}$ & $16.783 \mathrm{bB}$ & $5.585 \mathrm{bD}$ \\
\hline & Total & $142.866 \mathrm{~A}$ & $90.893 \mathrm{~B}$ & $90.526 \mathrm{~B}$ & $48.174 \mathrm{C}$ \\
\hline \multirow{4}{*}{$\begin{array}{l}\text { Energy Productivit } \\
(\text { Gcal ha-1) }\end{array}$} & Wood & $392.340 \mathrm{aA}$ & $205.645 \mathrm{aB}$ & $190.834 \mathrm{aB}$ & $118.632 \mathrm{aC}$ \\
\hline & Bark & $61.521 \mathrm{cA}$ & $56.100 \mathrm{bcB}$ & $52.438 \mathrm{cC}$ & $24.493 \mathrm{bD}$ \\
\hline & Branch & $81.938 \mathrm{bA}$ & $51.514 \mathrm{cC}$ & $58.763 \mathrm{cB}$ & $35.853 \mathrm{bD}$ \\
\hline & Leaf & $84.285 \mathrm{bA}$ & $76.553 \mathrm{bB}$ & $81.716 \mathrm{bA}$ & $26.668 \mathrm{bC}$ \\
\hline Gross Calorific & Wood & $4312 b$ & $4317 \mathrm{~b}$ & $4070 \mathrm{c}$ & $4320 \mathrm{~b}$ \\
\hline \multirow[t]{3}{*}{ Value $\left(\mathrm{kcal} \mathrm{kg}^{-1}\right)$} & Bark & $3778 \mathrm{c}$ & $3607 \mathrm{c}$ & $3874 \mathrm{c}$ & $3500 \mathrm{c}$ \\
\hline & Branch & $4517 \mathrm{~b}$ & $4376 \mathrm{~b}$ & $4412 \mathrm{~b}$ & $4410 \mathrm{~b}$ \\
\hline & Leaf & $4829 \mathrm{a}$ & $4805 \mathrm{a}$ & $4869 \mathrm{a}$ & $4775 \mathrm{a}$ \\
\hline \multirow{4}{*}{$\begin{array}{l}\text { Fixed Carbon } \\
(\%)\end{array}$} & Wood & $14.91 \mathrm{~b}$ & $15.81 \mathrm{~b}$ & $15.25 \mathrm{~b}$ & $14.36 \mathrm{~b}$ \\
\hline & Bark & $19.02 \mathrm{a}$ & $20.98 \mathrm{a}$ & $19.09 \mathrm{a}$ & $18.74 \mathrm{a}$ \\
\hline & Branch & $15.93 \mathrm{~b}$ & $16.50 \mathrm{~b}$ & $15.87 \mathrm{~b}$ & $14.82 \mathrm{~b}$ \\
\hline & Leaf & $20.36 \mathrm{a}$ & $21.75 \mathrm{a}$ & $16.96 \mathrm{~b}$ & $16.64 \mathrm{ab}$ \\
\hline Volatile & Wood & $83.23 \mathrm{a}$ & $83.76 \mathrm{a}$ & $84.46 \mathrm{a}$ & $84.53 \mathrm{a}$ \\
\hline \multirow[t]{3}{*}{ Material (\%) } & Bark & $75.29 \mathrm{~b}$ & $77.95 \mathrm{~b}$ & $77.74 \mathrm{~b}$ & $77.15 \mathrm{~b}$ \\
\hline & Branch & $83.17 \mathrm{a}$ & $83.91 \mathrm{a}$ & $81.60 \mathrm{a}$ & $83.58 \mathrm{a}$ \\
\hline & Leaf & $75.83 \mathrm{~b}$ & $78.27 \mathrm{~b}$ & $77.87 \mathrm{~b}$ & $77.88 \mathrm{~b}$ \\
\hline \multirow{4}{*}{$\begin{array}{l}\text { Ash Content } \\
(\%)\end{array}$} & Wood & $0.84 \mathrm{c}$ & $0.74 \mathrm{c}$ & $0.67 \mathrm{c}$ & $0.65 \mathrm{c}$ \\
\hline & Bark & $4.75 \mathrm{a}$ & $3.97 \mathrm{a}$ & $4.00 \mathrm{a}$ & $4.51 \mathrm{a}$ \\
\hline & Branch & $2.13 \mathrm{~b}$ & $2.28 \mathrm{~b}$ & $2.28 \mathrm{~b}$ & $1.96 \mathrm{~b}$ \\
\hline & Leaf & $4.14 \mathrm{a}$ & $4.75 \mathrm{a}$ & $4.71 \mathrm{a}$ & $4.75 \mathrm{a}$ \\
\hline $\mathrm{BD}\left(\mathrm{g} \mathrm{cm}^{-3}\right)$ & Wood & 0.367 & 0.371 & 0.365 & 0.384 \\
\hline ED $\left(\right.$ Gcal m$\left.{ }^{-3}\right)$ & Wood & 1.582 & 1.590 & 1.591 & 1.661 \\
\hline
\end{tabular}

Where: BD = Basic Density; ED = Energy Density; Comp. = compartments; Averages followed by lowercase letters in the same column and equal capital letters in the line do not differ among species and spacings, respectively, $5 \%$ of error probability according to Tukey's range test.

for all assessed variables. In general, a growing trend of compartments was observed, especially in wood, for BIO and EP variables, in relation to the different years evaluated, with no tendency to stabilization since the evaluation period influenced compartments of the trees production.

Although significant models for ED and EP along the three periods (Figure 1) were identified, it was observed that there is not a systematic variation in increase or decrease for these variables over time, consequently, a clear trend wasn't detected. Therefore, it is emphasized the importance of those variables that consider the energy contained in a determined volume and weight of wood, respectively.

\section{DISCUSSION}

According to Oliveira Neto et al. (2003), there is a bigger production of BIO per unit of area in the minor spacings, mainly due to the larger number of individuals. This justifies the decreasing trends in BIO production in the different compartments of the plants, due to the increase of planting spacing. Though, Müller et al. (2005) emphasize that, over time, the amount of stored wood on a particular location tends to level off at different spacings, even though in the higher densities occurs stagnation of growth at earlier ages and in the plantations with broader spacings it appears at advanced ages.

The values observed in this study were lower than those found in the literature with populations of different

Revista Árvore, Viçosa-MG, v.40, n.4, p.749-758, 2016 
Table 3 - Average test for energy variables of the compartments of Eucalyptus grandis, distributed in different spacings, five years after planting in the city of Frederico Westphalen-Rio Grande do Sul.

Tabela 3 - Teste de médias para as variáveis energéticas dos compartimentos das árvores de Eucalyptus grandis, distribuídas em diferentes espaçamentos, cinco anos após o plantio, no municipio de Frederico Westphalen-RS.

\begin{tabular}{|c|c|c|c|c|c|}
\hline \multirow[t]{2}{*}{ Varible } & \multirow[t]{2}{*}{ Comp. } & \multicolumn{4}{|c|}{ Spacing (m) } \\
\hline & & $2.0 \times 1.0$ & $2.0 \times 1.5$ & $3.0 \times 1.0$ & $3.0 \times 1.5$ \\
\hline \multirow{5}{*}{$\begin{array}{l}\text { Biomass } \\
(\text { ton ha-1) }\end{array}$} & Wood & $279.016 \mathrm{aA}$ & $244.275 \mathrm{aB}$ & $228.725 \mathrm{aC}$ & $190.086 \mathrm{aD}$ \\
\hline & Bark & $11.067 \mathrm{bcA}$ & $9.991 \mathrm{cA}$ & $10.635 \mathrm{cAB}$ & $10.167 \mathrm{cBC}$ \\
\hline & Branch & $19.021 \mathrm{bA}$ & $18.152 \mathrm{bA}$ & $22.195 \mathrm{bA}$ & $19.614 \mathrm{bA}$ \\
\hline & Leaf & $16.046 \mathrm{bcB}$ & $14.172 \mathrm{bcC}$ & $18.612 \mathrm{bA}$ & $14.142 \mathrm{bcC}$ \\
\hline & Total & $325.150 \mathrm{~A}$ & $286.590 \mathrm{~B}$ & $280.167 \mathrm{~B}$ & $234.009 \mathrm{C}$ \\
\hline \multirow{4}{*}{$\begin{array}{l}\text { Energy Productivit } \\
(\text { Gcal ha-1) }\end{array}$} & Wood & $1233.530 \mathrm{aA}$ & $1104.367 \mathrm{aB}$ & $1009.821 \mathrm{aC}$ & $871.734 \mathrm{aD}$ \\
\hline & Bark & $42.210 \mathrm{cA}$ & $40.284 \mathrm{cA}$ & $39.903 \mathrm{cA}$ & $39.895 \mathrm{cA}$ \\
\hline & Branch & $84.853 \mathrm{bBC}$ & $79.252 \mathrm{bC}$ & $97.192 \mathrm{bA}$ & 86.949 bB \\
\hline & Leaf & $81.113 \mathrm{bB}$ & $70.744 \mathrm{bC}$ & $93.563 \mathrm{bA}$ & $70.017 \mathrm{bC}$ \\
\hline \multirow{4}{*}{$\begin{array}{l}\text { Gross Calorific } \\
\text { Value }\left(\mathrm{kcal} \mathrm{kg}^{-1}\right)\end{array}$} & Wood & $4421 \mathrm{~b}$ & $4521 \mathrm{~b}$ & $4415 \mathrm{~b}$ & $4586 \mathrm{~b}$ \\
\hline & Bark & $3814 \mathrm{c}$ & $4032 \mathrm{c}$ & $3752 \mathrm{c}$ & $3924 \mathrm{c}$ \\
\hline & Branch & $4461 \mathrm{~b}$ & $4366 \mathrm{~b}$ & $4379 \mathrm{~b}$ & $4433 \mathrm{~b}$ \\
\hline & Leaf & $5055 \mathrm{a}$ & 4992 a & $5027 \mathrm{a}$ & $4951 \mathrm{a}$ \\
\hline \multirow{4}{*}{$\begin{array}{l}\text { Fixed Carbon } \\
(\%)\end{array}$} & Wood & $19.50 \mathrm{ab}$ & $19.38 \mathrm{ab}$ & $20.02 \mathrm{a}$ & $19.44 \mathrm{ab}$ \\
\hline & Bark & $21.91 \mathrm{a}$ & $22.10 \mathrm{a}$ & $20.80 \mathrm{a}$ & $19.90 \mathrm{ab}$ \\
\hline & Branch & $18.72 \mathrm{~b}$ & $18.57 \mathrm{~b}$ & $18.96 \mathrm{~b}$ & $19.19 \mathrm{~b}$ \\
\hline & Leaf & $20.54 \mathrm{a}$ & $21.90 \mathrm{a}$ & $19.78 \mathrm{ab}$ & $21.26 \mathrm{a}$ \\
\hline \multirow{4}{*}{$\begin{array}{l}\text { Volatile Material } \\
(\%)\end{array}$} & Wood & $80.30 \mathrm{a}$ & $80.65 \mathrm{a}$ & $80.00 \mathrm{a}$ & $80.32 \mathrm{a}$ \\
\hline & Bark & $72.18 \mathrm{c}$ & $72.00 \mathrm{c}$ & $75.05 \mathrm{~b}$ & $73.84 \mathrm{c}$ \\
\hline & Branch & $78.14 \mathrm{ab}$ & $78.08 \mathrm{ab}$ & $77.71 \mathrm{~b}$ & $77.99 \mathrm{~b}$ \\
\hline & Leaf & $74.22 \mathrm{bc}$ & $73.33 \mathrm{c}$ & $74.84 \mathrm{~b}$ & $73.77 \mathrm{c}$ \\
\hline \multirow{4}{*}{$\begin{array}{l}\text { Ash Content } \\
(\%)\end{array}$} & Wood & $0.62 \mathrm{c}$ & $0.58 \mathrm{c}$ & $0.63 \mathrm{c}$ & $0.68 \mathrm{~b}$ \\
\hline & Bark & $5.58 \mathrm{a}$ & $5.65 \mathrm{a}$ & $4.63 \mathrm{a}$ & $4.90 \mathrm{a}$ \\
\hline & Branch & $2.76 \mathrm{~b}$ & $2.54 \mathrm{~b}$ & $2.87 \mathrm{~b}$ & $2.58 \mathrm{~b}$ \\
\hline & Leaf & $4.87 \mathrm{a}$ & $5.08 \mathrm{a}$ & $5.05 \mathrm{a}$ & $5.34 \mathrm{a}$ \\
\hline $\mathrm{BD}\left(\mathrm{g} \mathrm{cm}^{-3}\right)$ & Wood & 0.390 & 0.417 & 0.392 & 0.401 \\
\hline $\mathrm{ED}\left(\mathrm{Gcal} \mathrm{m} \mathrm{m}^{-3}\right)$ & Wood & 1.724 & 1.885 & 1.731 & 1.839 \\
\hline
\end{tabular}

ages. Lima et al. (2011) reported an average productivity of biomass of the E. benthamii bole, 416 ton ha-1 ton $\mathrm{ha}^{-1}$ at 6 years old. Brito et al. (1983) reported values for E. saligna, 405.6 ton $\mathrm{ha}^{-1}$ and E. grandis $(518.2$ ton $\left.\mathrm{ha}^{-1}\right)$ at 10 years old. This data is verified by authors who have developed several works related to the influence of planting spacing and age of the population in the production of forest populations, presenting a difference in the distribution of BIO among the species and in the same species (MÜLLER et al., 2005).

The average values for E. grandis GCV are in accordance with those reported in the literature. In studies based on Hofler et al. (2010), average values were observed in 3, 5 and 7 year-old Eucalyptus clones respectively, equivalent to $3,348,4,529$ and 4,378 kcal $\mathrm{kg}^{-1}$. Likewise, Quirino et al. (2005) conducted a literature review related to GCV of wood from 258 exotic and native tropical forest species, and reported that the average values were $4,710 \mathrm{kcal} \mathrm{kg}^{-1}$, ranging from 3,831 to $5,324 \mathrm{kcal} \mathrm{kg}^{-1}$.

Santana (2009) verified that the GCV is little influenced by age, so a conclusive trend can't be confirmed. The same author mentions that factors related to the structural composition of wood positively influence its energy potential, especially those with regard to chemical and elemental constitution. In contrast, Lemenih and Bekele (2004), by evaluating the effect of age on the GCV of wood in Eucalyptus species, mention a negative relationship with the age of the tree, presenting a small difference between the ages 

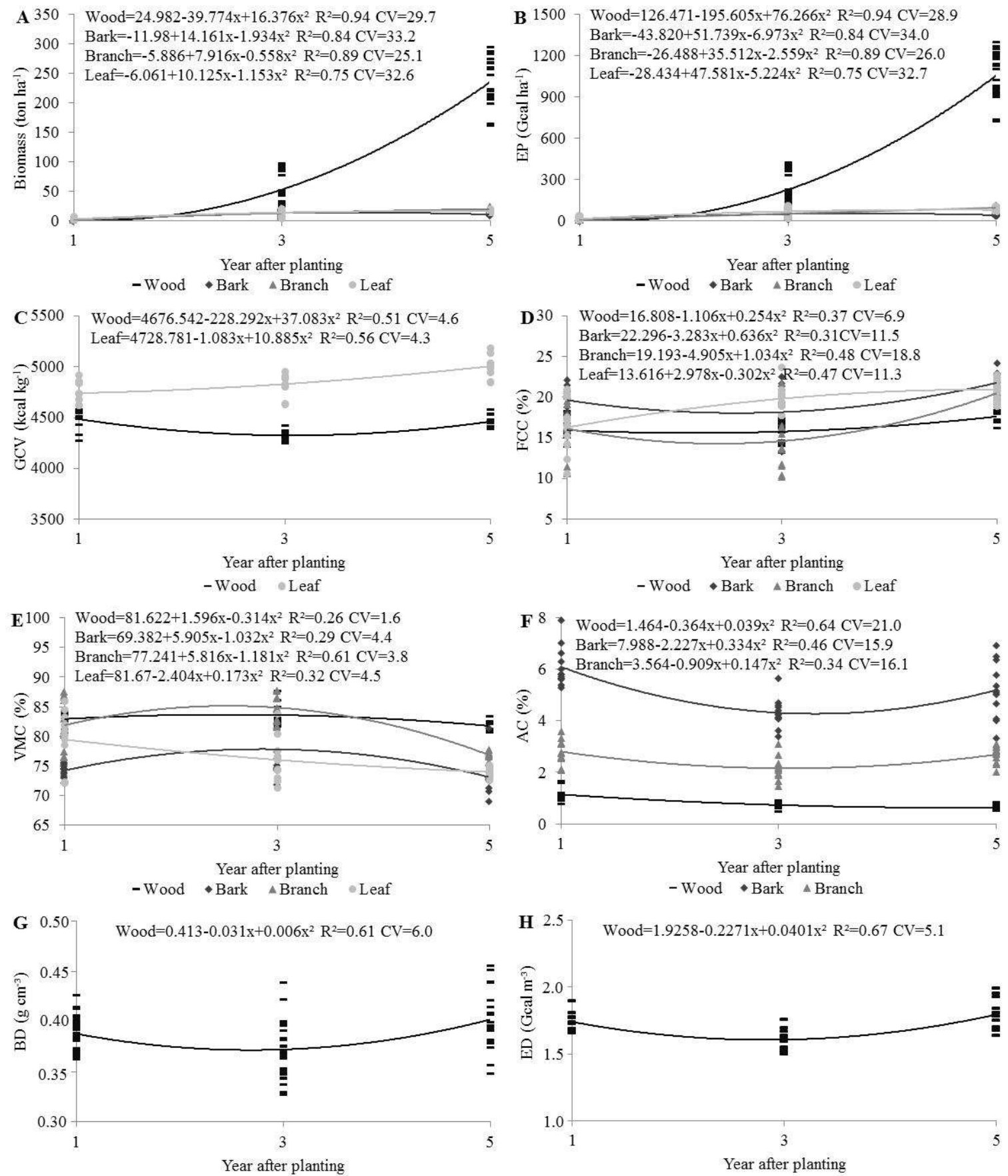

Figure 1 - Regression equations for biomass (A), energy productivity (EP) (B), Gross Calorific Value (GCV) (C), Fixed Carbon Content (FCC) (D), Volatile Material Content (VMC) (E), Ash Content (AC) (F), Basic Density (BD) (G) and Energy Density (ED) (H) in the $1^{\text {st }}, 3^{\text {rd }}$ and $5^{\text {th }}$ year after planting in the city of Frederico Westphalen-RS.

Figura 1 - Equações de regressão para a biomassa (A), produtividade energética $(E P)(B)$, poder calorífico superior (GVC) (C), teor de carbono fixo (FCC) (D), teor de materiais voláteis $(V M C)(E)$, teor de cinzas $(A C)(F)$, massa especifica básica $(B D)(G)$ e densidade energética $(E D)(H)$, no $1^{\circ}, 3^{\circ}$ e $5^{\circ}$ ano após o plantio, no município de Frederico Westphalen-RS. 
of 11-21. Similar results were reported by Vidaurre et al. (2012) with Schizolobium amazonicum, reporting that the youngest age had the highest GCV values, with a downward trend with the increasing age of the tree.

VMC and FCC levels in wood are according to Brito and Barrichello (1982), who delimit, in general, the $\mathrm{VMC}$ content ranging from $75 \%$ to $85 \%$, and the FCC from $15 \%$ to $25 \%$. According to these authors, combustibles with high FCC rates are desirable, as they perform a slower burning, resulting in a longer residence time inside the machines. According Vieira et al. (2013), the VMC content positively interferes in the ignition facilitating it, although the combustion process is fast. For these authors, the AC content is undesirable for an energy product, reducing the GCV and causing loss of efficiency of the product, because it corresponds to substances that do not burn when in solid form. Botrel et al. (2010), working with eight Eucalyptus clones, found $\mathrm{AC}$ values ranging from 0.11 to $0.25 \%$.

In relation to $\mathrm{BD}$, the results observed in this study are within the range that Quirino et al. (2005) reported for 108 forest species, ranging from 0.200 to $1.080 \mathrm{~g}$ $\mathrm{cm}^{-3}$. They also corroborate the results observed by Eloy et al. (2014), who found no effect of spacing in the BD of the wood. However, they are different from those found by Pauleski (2010), which reported an increase on BD with the increase of planting spacing. In contrast, Garcia et al. (1991) reported a decrease of the BD of the wood with the increase of spacing in wood from E. grandis and E. saligna. For Eloy et al. (2013) those differences in the results could be due to several factors, such as genetic variability of the populations and different environmental conditions, based on the different ages.

The difference in BD observed in those periods is supported by several authors who have studied this technological characteristic. Trevisan et al. (2012), by studying the influence of thinning in central trees of E. grandis aged 4-18, found a variation in the average BD values of 0.390 to $0.462 \mathrm{~g} \mathrm{~cm}^{-3}$, confirming the existence of variability within species and among the different ages of the populations.

The ED that considers the energy contained in a specific volume of wood was more influenced by the SG than the GCV that varied less. For Moreira et al. (2012), the BD and the GCV vary among the species, among individuals from the same species according to their age, justifying the reported variation in this work. Neves et al. (2013) reported that for Eucalyptus clones, at 4.5 and 5.6 years, the values of this variable are 2.051 and $2.084 \mathrm{Gcal} \mathrm{m}^{-3}$, respectively.

Similar results of EP were obtained by Santana (2009), by studying E. grandis and E. urophylla, reported differences among ages and spacings, and the highest values were identified in advanced ages and more dense spacings.

\section{CONCLUSION}

Age and planting spacing influence in the biomass energy properties of the different compartments of Eucalyptus grandis.

The three ages induce a significant effect for all analyzed variables, so in the $5^{\text {th }}$ year after planting are verified the higher biomass levels, energy productivity, basic density, energy density and fixed carbon content.

Through the different ages, biomass and energy productivity of wood are superior than other compartments of the trees, so the biggest contributions to biomass follow the order wood $>$ branch $>$ leaf $>$ bark.

The four planting spacings provide different biomass productions and energy productivity by reducing their values with the increase of spacing, in all assessed periods.

From the energy point of view, the higher the age and lower the planting spacing, the better the biomass energy properties.

\section{REFERÊNCIAS}

ASSOCIAÇÃO BRASILEIRA DE NORMAS TÉCNICAS - ABNT. NBR 11941:

Determinação da densidade básica da madeira. Rio de Janeiro: 2003. 6p.

ASSOCIAÇÃO BRASILEIRA DE NORMAS TÉCNICAS - NBR 8112: carvão vegetal: análise imediata. Rio de Janeiro: 1986. 6p.

ASSOCIAÇÃO BRASILEIRA DE NORMAS TÉCNICAS - NBR 8633: carvão vegetal: Determinação do poder calorífico superior. Rio de Janeiro: 1984. 13p. 
BOTREL, M.C.G.; TRUGILHO, P.F.; ROSADO, S.C.S.; MOREIRA DE SILVA, J.R. Seleção de clones de Eucalyptus para biomassa florestal e qualidade da madeira. Scientia Forestalis, v.38, n.86, p.237-245, 2010.

EMPRESA DE PESQUISA ENERGÉTICA - EPE. Balanço Energético Nacional 2014: ano base 2013. Rio de Janeiro: 2014. 288p.

BRITO, J.O.; BARRICHELO, L.E.G.; SEIXAS, F.; MIGLIORINI, A.J.; MURAMOTO, M.C. Análise da produção energética e de carvão vegetal de espécies de eucalipto. IPEF, n.23, p.53-56, 1983.

BRITO, J.O.; BARRICHELO, L.E.G. Aspectos técnicos da utilização da madeira e carvão vegetal como combustíveis. In: SEMINÁRIO DE ABASTECIMENTO ENERGÉTICO INDUSTRIAL COM RECURSOS FLORESTAIS, 2., 1982, São Paulo. São Paulo: 1982. p.101-137.

CARON, B.O.; ELOY, E.; SOUZA, V.Q.; SCHMIDT, D.; BALBINOT, R.; BEHLING, A.; MONTEIRO, G.C. Quantificação da Biomassa florestal em plantios de curta rotação com diferentes espaçamentos. Comunicata Scientiae, v.6, n.1, p.106-112, 2015.

ELOY, E. Quantificação e caracterização da biomassa florestal em plantios de curta rotação. 2013. 88f. Dissertação (Mestrado em Agronomia) - Universidade Federal de Santa Maria, Frederico Westphalen, 2013.

ELOY, E.; CARON, B.O.; TREVISAN, R.; SCHMIDT, D.; ZANON, M.L.B.; BEHLING, A.; MONTEIRO, G.C. Variação longitudinal e efeito do espaçamento na massa específica básica da madeira de Mimosa scabrella e Ateleia glazioveana. Floresta, v.43, n.2, p.327-334, 2013.

ELOY, E.; CARON, B.O.; SILVA, D.A.; SCHMIDT, D.; TREVISAN, R.; BEHLING, A.; ELLI, E.F. Influência do espaçamento nas características energéticas de espécies arbóreas em plantios de curta rotação. Revista Árvore, v.38, n.3, p.551-559, 2014.

ELOY, E.; CARON, B.O.; SILVA, D.A.; SOUZA, V.Q.; TREVISAN, R.; BEHLING, A.; ELLI, E.F. Produtividade energética de espécies florestais em plantios de curta rotação. Ciência Rural, v.45, n.8, p.1424-1431, 2015.
EMPRESA BRASILEIRA DE PESQUISA AGROPECUÁRIA - EMBRAPA. Sistema brasileiro de classificação de solos. $2^{\mathrm{a}}$.ed. Rio de Janeiro: 2006. 412p.

GARCIA, C.H.; CORRADINE, L.; ALVARENGA, S.F. Comportamento florestal do Eucalyptus grandis e Eucalyptus saligna em diferentes espaçamentos. IPEF Circular Técnica, n.179, p.1-8, 1991.

HOFLER, J.; BIANCHI, M.L.; SOARES, V.C. Variação da composição química e poder calorífico da madeira de clones de Eucalyptus de diferentes idades. $33^{a}$ Reunião anual da sociedade brasileira de química, 2010, Águas de Lindóia-SP.

LEMENIH, M.; BEKELE, T. Effect of age on calorific value and some mechanical properties of three Eucalyptus species grown in Ethiopia. Biomass e Bioenergy, v.27, p.223-232, 2004.

LIMA, E.A.; SILVA, H.D.; LAVORANTI, O.J. Caracterização dendroenergética de árvores de Eucalyptus benthamii. Pesquisa Florestal Brasileira, v.31, n.65, p.9-17, 2011.

MALUF, J.R.T. Nova classificação climática do Estado do Rio Grande do Sul. Revista Brasileira de Agrometeorologia, v.8, n.1, p.141-150, 2000.

MOREIRA, J.M.M.A.P.; LIMA, E.A.; GOULART, I.C.G.R. Impacto do teor de umidade e da espécie florestal no custo da energia útil obtida a partir da queima da lenha. Colombo: 2012. 5p. (Comunicado Técnico Embrapa, 293)

MOREIRA, J.M.M.A.P. Potencial de participação das florestas na matriz energética. Pesquisa Florestal Brasileira, v.31, n.68, p.363-372, 2011.

MÜLLER, M.D.; COUTO, L.; LEITE, H.G.; BRITO, J.O. Avaliação de um clone de eucalipto estabelecido em diferentes densidades de plantio para produção de biomassa e energia. Biomassa \& Energia, v.2, n.3, p.177-186, 2005.

NEVES, T.A.; PROTÁSIO, T.P.; TRUGILHO, P.F.; VALLE, M.L.A.; SOUSA, L.C.; VIEIRA, C.M.M.

Revista Árvore, Viçosa-MG, v.40, n.4, p.749-758, 2016 
Qualidade da madeira de clones de Eucalyptus em diferentes idades para a produção de bioenergia. Revista Ciências Agrárias, v.56, n.2, p.139$148,2013$.

OILIVEIRA NETO, S.N.; REIS, G.G.; REIS, M.G.F.; NEVES, J.C.L. Produção e distribuição de biomassa em Eucalyptus camaldulensis Dehn. em resposta à adubação e ao espaçamento. Revista Árvore, v.27, n.1, p.15-23, 2003.

PAULESKI, D.T. Influência do espaçamento sobre o crescimento e a qualidade da madeira de Pinus taeda L.. 2010. 198f. Tese (Doutorado em Engenharia Florestal) -

Universidade Federal de Santa Maria, Santa Maria, 2010.

PROTÁSIO, T.P.; COUTO, A.M.; REIS, A.A.; TRUGILHO, P.F. Seleção de clones de Eucalyptus para a produção de carvão vegetal e bioenergia por meio de técnicas univariadas e multivariadas.

Sientia Forestalis, v.41, n.97, 2013.

QUIRINO, W.F.; VALE, A.T.; ANDRADE, A.P.A.; ABREU, V.L.S.; AZEVEDO, A.C.S. Poder calorífico da madeira e de materiais ligno-celulósicos. Revista da Madeira, v.15, n.89, p.100-106, 2005.

SANQUETTA, C.R. Métodos de determinação de biomassa florestal. In: SANQUETTA, C.R. (Ed.).
As florestas e o carbono. Curitiba: 2002. p.119-140.

SANTANA, W.M.S. Crescimento, produção e propriedades da madeira de um clone de Eucalyptus grandis e E. urophylla com enfoque energético. 2009. $91 \mathrm{f}$.

Dissertação (Mestrado em Tecnologia da Madeira) - Universidade Federal de Lavras, Lavras, 2009.

SILVA, D.A.; CARON, B.O.; BEHLING, A.; SOUZA, V.Q.; ELOY, E. Ponto de amostragem ao longo do fuste para estimativa do poder calorífico da madeira. Ciência Rural, v.42, n.9, p. 1588-1595, 2012.

TREVISAN, R.; ELOY, E.; DENARDI, L.;

HASELEIN, C.R.; CARON, B.O. Variação axial e efeito do desbaste na massa específica das árvores centrais de Eucalyptus grandis. Ciência Rural, v.42, n.2, p.312-318, 2012.

VIDAURRE, G.B.; CARNEIRO, A.C.O.; VITAL, B.R.; SANTOS, R.C.; VALLE, M.L.A. Propriedades energéticas da madeira e do carvão de paricá (Schizolobium amazonicum) Revista Árvore, v.36, n.2, p.365-371, 2012.

VIEIRA, A.C.; SOUZA, S.N.M.; BARICCATTI, R.A.; SIQUEIRA, J.A.C.; NOGUEIRA, C.E.C. Caracterização da casca de arroz para geração de energia. Revista Varia Scientia Agrárias, v. 3, n. 1, p. 51-57, 2013. 